\title{
MANAJEMEN PENERIMAAN PESERTA DIDIK BARU DI SDIT KI HAJAR DEWANTORO KECAMATAN TAMBUN SELATAN KABUPATEN BEKASI
}

\author{
Baharuddin $^{1}$, Diyah Yuli Sugiarti ${ }^{2,}$ Dewi Aryanti, \\ St. Rajiah ${ }^{4}$, Nurhaeni ${ }^{5}$, Burhan ${ }^{6}$ \\ Universitas Muhammadiyah Makassar ${ }^{1,4,5}$, Universitas Islam 45 Bekasi $^{2}$ \\ SDIT Satu Syawal ${ }^{3}$, Universitas Madako ${ }^{6}$ \\ auliaburhan25@gmail.com $^{6}$
}

\begin{abstract}
ABSTRAK
Penelitian ini bertujuan untuk menganalisis manajemen penerimaan peserta didik baru di SDIT Ki Hajar Dewantoro. Penelitian ini menggunakan metode penelitian deskriptif kualitatif. Dari hasil penelitian, analisis manajemen penerimaan peserta didik baru menggunakan analisis SWOT. Dengan melihat kekuatan (strengths), kelemahan (weaknesses), peluang (opportunities) dan ancaman (treats) sehingga sekolah mengetahui dan dapat dijadikan masukan untuk tahun yang akan datang, agar jumlah peserta didik baru dari tahun ke tahun mengalami peningkatan. Simpulan, manajemen sekolah membuat perencanaan semua kegiatan-kegiatan dan program-program sekolah diantaranya; adanya program sekolah sebagai ciri khas sekolah/program unggulan, promosi sekolah, bagaimana sekolah dalam mengimplementasikan rencana kerjanya baik jangka panjang, menengah dan pendek, serta adanya usaha kerja sama didalam manajemen sekolah antara kepala sekolah, guru, orang tua, siswa dan masyarakat agar sekolah dapat dikelola secara efektif.
\end{abstract}

Kata Kunci: Analisis Manajemen, Peserta Didik

\begin{abstract}
This study aims to analyze the management of admission of new students at SDIT Ki Hajar Dewantoro. This research uses descriptive qualitative research methods. From the results of the study, management analysis of new student admissions uses SWOT analysis. By looking at strengths, weaknesses, opportunities and threats so the school knows and can be used as input for the coming year, so the number of new students increases from year to year. In conclusion, school management plans all school activities and programs including; the existence of a school program as a hallmark of a superior school / program, school promotion, how schools implement their long, medium and short term work plans, and collaborative efforts in school management between school principals, teachers, parents, students and the community so that schools can be managed effectively.
\end{abstract}

Keywords: Management Analysis, Students 


\section{PENDAHULUAN}

Manajemen Penerimaan Peserta Didik Baru (PPDB) dilakukan agar tujuan sekolah dalam memberikan layanan untuk masyarakat terutama calon peserta didik dapat dicapai dengan baik. Kepercayaan masyarakat terhadap lembaga pendidikan perlu ditingkatkan. Untuk itu diperlukan pendekatan sistem agar efetivitas dan efisien juga meningkat.Lembaga-lembaga pendidikan menjadi semakin kompleks dan semakin sulit untuk dikelola. Cara-cara tradisional dalam manajemen tidak mampu lagi atau kurang efktif untuk menyelesaikan masalah, tanpa didukung oleh tehnologi informasi internet. Apalagi kaitannya dengan Penerimaan Peserta Didik Baru (PPDB) tidak hanya brosur saja dalam mempromisikannya tetapi harus juga merambah ke tehmologi informasi agar siapa saja yang membutuhkan informasi dapat langsung membuka website yang didalamnya terdapat dari awal proses penerimaan peserta didik baru sampai kepada program sekolah yang sudah ditetapkan sebelumnya dan sudah terimplementasi oleh output dari sekolah tersebut, khususnya SDIT Ki Hajar Dewantoro. Tanpa itu sulit terlaksana dengan maksimal.Selain hal tersebut juga pembinaan dan kerjasama yang baik dengan para alumni serta orang tua alumni harus dibina dengan baik, sehingga mereka dapat menjadi marketing untuk sekolah tersebut secara langsung dari mulut ke mulut. Mengingat SDIT Ki Hajar Dewantoro memiliki potensi untuk berkembang dalam peserta didik barunya asalkan didalam manajemen penerimaan peserta didik baru didukung oleh semua komponen-komponennya (Marini, 2014).

Faktor lain yang tidak kalah penting yang harus dilakukan oleh sekolah adalah secara terus-menerus untuk berkomunikasi, dengan para pejabat pendidikan di wilayah kerjanya. Dengan demikian, berbagai permasalahan pun segera dapat dibahas dan diselesaikan. Demikian halnya dengan keberadaan masyarakat sekitar sekolah dan keberadaan sekolah yang seharusnya saling berinteraksi dan bersinergi sehingga sekolah akan berkembang dengan baik dan diterima oleh masyarakat. Sebaliknya, masyarakat juga akan diuntungkan oleh lulusan yang berkualitas baik dan diwarnai dengan berbagai program kegiatan yang baik diawal masuk ke sekolah, hal ini terkait dengan penerimaan peserta didik baru, juga didukung dengan kompetensi profesional dari guru yang ada di sekolah tersebut. Faktor kenyamanan peserta didik dari awal masuk gerbang sekolah sampai ke dalam pembelajaran juga menjadi penentu dalam penerimaan peserta didik baru, mengingat sekolah ini melewati panti rehabilitasi mental. Intinya adalah, masyarakat yang diposisikan sebagai pelanggan (costumer) sekolah harus dilayani dengan baik oleh sekolah, bahwa masyarakat dapat memberikan dukungan semaksimal mungkin dalam pengembangan sekolah tersebut.Caranya adalah sekolah harus dapat menyusun dan menjelaskan program sekolah yang sangat rasional dan mudah untuk dipahami oleh para orangtua dan masyarakat sekitarnya.Hal itu agar masyarakat mengetahui betul berbagai kegiatan sekolah yang baik dan unggul bagi masyarakat yang ingin membantu sekolah, dengan melihat suatu program yang dapat dikembangkannya (Sukarti, Susuri, 2017).

Program-program sekolah dilakukan dalam bentuk ekstrakulikuler atau program unggulan keagamaan, yang dapat melibatkan berbagai komponen masyarakat yang ahli dibidangnya untuk berperan serta dalam membangun program sekolah, sebagai sebuah tambahan identitas sekolah tersebut. Semakin 
jelas informasi suatu sekolah yang disampaikan kepada masyarakat, maka akan semakin menarik simpati dari masyarakat, sehingga dalam penerimaan peserta didik baru di SDIT Ki Hajar Dewantoro dapat meningkat.

Penerimaan peserta didik baru di sebuah lembaga pendidikan (sekolah) pada hakikatnya adalah merupakan proses pencarian, menentukan dan menarik pelamar yang mampu untuk menjadi peserta didik di lembaga pendidikan (sekolah) yang bersangkutan. Penerimaan siswa merupakan proses pendataan dan pelayanan siswa yang baru masuk sekolah, setelah mereka memenuhi persyaratan yang telah ditetapkan oleh sekolah tersebut (Sukarti, Susuri, 2017).

Langkah-langkah penerimaan peserta didik baru sebagai berikut : Pembentukan panitia penerimaan peserta didik baru. Pembuatan dan pemasangan pengumuman PPDB. Tahap seleksi siswa melalui tes atau ujian. Melalui penelusuran bakat kemampuan. Berdasarkan nilai STTB atau nilai UAN

Komponen peserta didik keberadaannya sangat dibutuhkan, terlebih bahwa pelaksanaan kegiatan pendidikan di sekolah, peserta didik merupakan subyek sekaligus objek dalam proses transformasi ilmu pengetahuan dan keterampilanketerampilan yang diperlukan. Oleh karena itu keberadaan peserta didik tidak hanya sekedar memenuhi kebutuhan saja, akan tetapi harus merupakan bagian dari kebermutuan dari lembaga pendidikan (sekolah). Artinya bahwa dibutuhkan pengelolaan manajemen peserta didik yang bermutu bagi lembaga pendidikan (sekolah) itu sendiri.Sehingga peserta didik itu dapat tumbuh dan berkembang sesuai dengan potensi fisik, kecerdasan intektual, sosial, emosional, dan kejiwaan peserta didik Layanan kepada siswa dimulai sejak dari penerimaan siswa baru, penempatan, pembinaan, pengembangan, dan pelayanan sampai dengan mereka lulus dari sekolah tersebut. Sekolah harus memiliki unit-unit pelayanan siswa sehingga mutu dan budaya mutu dapat diciptakan dengan baik

Sekolah harus memiliki manajemen strategik, manajemen sekolah serta analisis kekuatan, kelemahan, peluang dan ancaman (analisis swot) yang baik bagi kemajuan sekolah..Manajemen strategik adalah suatu organisasi mengandung tiga unsur yaitu analisis, keputusan dan aksi.Manajemen strategik berhubungan dengan analisis mengenai strategic goals (visi, misi dan tujuan) bersama dengan analisis lingkungan internal dan eksternal.Lebih lanjut manajemen puncak mesti membuat keputusan strategik.Setelah melakukan keputusan strategik, berikutnya adalah melakukan aksi (actions).Organisasi mesti melakukan aksi untuk mengimplementasikan strategi.Hal ini mengharuskan pimpinan untuk mengalokasikan sumber daya dan mengorganisasikannya dengan kapabilitas yang dimilikinya untuk melaksanakan strategi yang telah dirumuskan/diputuskannya.

Adapun manajemen sekolah dasar merupakan kegiatan mengelola atau mengatur sekolah dasar. Manajemen sekolah dasar memiliki dua aspek, yaitu: manajemen internal dan manajemen eksternal. Manajemen internal sekolah dasar meliputi pengakuan, manajemen perpustakaan, laboratorium, bangunan, serta sumber daya fisik dan material lainnya, sumber daya keuangan, ujian dan promosi, hubungan dengan kolega dan siswa.Manajemen eksternal meliputi hubungan dengan masyarakat, departemen dan orang-orang, serta pihak-pihak yang berhubungan dengan penetapan dan fungsi sekolah. Manajemen sekolah adalah usaha manusia yang bekerja sama, walaupun kepala sekolah adalah pengelola sekolah, kerja sama guru, orang tua, siswa, dan anggota masyarakat penting agar sekolah tersebut dapat dikelola secara efektif. 
Sedangkan analisa SWOT memapaparkan apa saja yang menjadi;(1) kekuatan/keunggulan yang dimiliki sekolah (Strenghts), (2) kelemahan (weaknesses) yang perlu diatasi, (3) peluang (opportunities) yang ada di sekolah untuk kedepannya (4) serta ancaman-ancaman (treats) tantangan nyata yang dihadapi sekolah. Dengan demikian apa yang sudah direncanakan di awal dapat berjalan dengan maksimal.

\section{METODE PENELITIAN}

Penelitian dilakukan di SDIT Ki Hajar Dewantoro, yang beralamat di Kp. Pulo RT. 04/037 Desa Sumber jaya, Kecamatan Tambun Selatan, Kabupaten Bekasi Provinsi Jawa barat, dibawah naungan Yayasan Bekti sumber Jaya Tambun Selatan.

Waktu penelitian ini dilakukan dua tahap pada tahap pra-obesrvasi dan observasi di Juni 2018 dan tahap penelitian lapangan di Juli 2018 serta penyusunan laporan penelitian dilakukan di Agustus 2018.

Yayasan ini mempunyai jenjang selain Sekolah Dasar Islam Terpadu (SDIT) terdapat Sekolah Menengah Pertama Islam Terpadu (SMPIT) dan Sekolah menengah Atas (SMAIT) selain itu juga adanya Pesantren. Dengan melihat dari tujuan sekolah: menjadikan siswa yang dewasa bertanggung jawab atas pilihannya, membentuk siswa memahami sunnatullah dengan jiwa sabar, istiqomah dan tawakal serta mencapai hidup selamat di dunia dan di akhirat, maka dapat disimpulkan bahwa tujuan awalnya adalah membentuk "karakter" anak, sehingga dari sisi manajemen nya belum maksimal, seperti manajeman penerimaan peserta didik baru, karena dengan melihat data yang diberikan oleh sekolah untuk semua rombongan belajar (rombel) dari kelas 1(satu) sampai dengan kelas 6 (enam) hanya 55 orang, dimana seharusnya sekolah ini memiliki lebih dari 55 orang peserta didik, apabila mempunyai manajemen yang dikelola dengan baik oleh stkakeholder, mengingat daya tampung sekolah ini masih banyak.

Metode penelitian yang digunakan peneliti menggunakan metode penelitian deskriptif kualitatif. Penelitian deskriptif (descriptive reseach) ditujukan untuk mendeskripsikan suatu keadaan atau fenomena-fenomena apa adanya.

Adapun data dan sumber data diperoleh dari: kepala sekolah, wakasek kurikulum, kesiswaan, guru, orang tua alumni dan tokoh masyarakat. Dengan menggunakan tehnik pengumpulan/perekaman data; observasi, wawancara dan dokumentasi.

Tehnik analisis data menggunakan. Analisis data kualitatif adalah proses mencari serta menyususn secara sistematis data yang diperoleh dari hasil wawancara, catatan lapangan, dan bahan-bahan lainnya sehingga mudah dipahami agar dapat diinformasikan kepada orang lain. Menurut Miles dan Huberman ada tiga macam kegiatan dalam analisis data kualitatif, yaitu : reduksi data, model data dan penarikan /verifikasi kesimpulan.Analisis data dalam penelitian kualitatif dilakukan sejak sebelum memasuki lapangan.Analisis telah mulai sejak merumuskan data dan menjelaskan masalah, sebelum terjun ke lapangan dan berlangsung terus sampai penulisan hasil penelitian. Namun dalam penelitian kualitatif, analisis data lebih difokuskan selama proses di lapangan bersamaan dengan pengumpulan data. 
Uji keabsahan data menggunakan Triangulasi data, Dalam kegiatan penelitian lapangan, peneliti mengajukan berbagai variasi pertanyaan kepada informan (narasumber) kemudian mencatatanya dalam catatan lapangan hasil observasi dan wawancara.Catatan lapangan hasil wawancara terdiri dari berbagai sumber data, kemudian membandingkan hasil wawancara untuk direchek kembali, dan disusun menuju kesimpulan.Untuk itu maka, peneliti melaksanakannya dengan jalan; (1) mengajukan berbagai macam variasi pertanyaan, (2) Mengeceknya dengan berbagai sumber data, (3) Memanfaatkan berbagai metode agar pengecekan kepercayaan data dapat dilakukan.

\section{HASIL PENELITIAN}

Hasil temuan penelitian di SDIT Ki hajar Dewantoro adalah bahwa;

Manajemen sekolah dalam membuat perencanaan kegiatan-kegiatan dan program-program sekolah., diantaranya dalam promosi sekolah masih belum maksimal, karena belum didukung dengan tehnologi informasi, belum adanya ciri khas/program-program sekolah unggulan. Belum mengacu kepada rencana kerja jangka menemgah/rencana kerja tengah semester.

Dalam segi pemasaran ataupun promosi sebaiknya sekolah dengan langkah langkah :

Memasarkan produk dari program-program sekolah melalui website atau tehnologi informasi sehingga memudahkan orang tua untuk mendaftar di sekolah tersebut.Menjalin hubungan kerja sama yang baik dengan TK/PAUD/BIMBA sekitar sekolah maupun dengan para alumni dan para orang tua alumni serta masyarakat sekitar sekolah, karena mereka adalah marketing yang handal yang untuk promosi dari mulut ke mulut.

Sekolah harus meningkatkan mutu pelayanan kepada siswa baik yang masih menuntut ilmu di sekolah ataupun kepada para alumni agar siswa-pun dapat menjadi marketing yang handal dalam mempromosikan sekolahnya apabila mereka mendapatkan pelayanan yang baik dari sekolah serta mempunyai kesan yang baik. Tak hanya itu, lebih bagus apabila di sekolah memiliki kantor yang disediakan untuk pengurus alumni, yang akan mempermudah komunikasi antara pengurus sekolah dengan pengurus alumni. Jika hubungan sekolah dengan alumni terbiina dengan baik maka sekolah dapat lebih berkembang melalui peran alumni tersebut, salah satunya membantu dalam segi promosi sekolah.

Sekolah harus mempunyai Analisis SWOT, dengan demikian sekolah dapat menganalisis keadaan internal dan eksternalnya.Menurut Freddy Rangkuti analisa SWOT dipaparkan apa saja yang menjadi : kekuatan/keunggulan yang dimiliki sekolah (Strenghts), kelemahan (weaknesses) yang perlu diatasi, peluang (opportunities) yang ada di sekolah untuk kedepannya serta ancaman-ancaman (treats) tantangan nyata yang dihadapi sekolah,

\section{PEMBAHASAN}

Menurut Arita Marini, Manajemen sekolah dasar merupakan kegiatan mengelola atau mengatur sekolah dasar. Manajemen sekolah dasar memiliki dua aspek, yaitu: manajemen internal dan manajemen eksternal. Manajemen sekolah dasar meliputi kegiatan-kegiatan.Perencanaan semua kegiatan-kegiatan dan program-program sekolah, diantaranya adalah promosi sekolah. 
Demikian menurut Fatah (2009) perencanaan adalah proses penentuan tujuan atau sasaran yang hendak dicapai dan menetapkan jalan dan sumber yang diperlukan untuk mencapai tujuan itu seefesien dan seefektif mungkin. Didalam perencanaan ada tiga kegiatan yang satu dengan yang lainnya tidak dapat dipisahkan dalam proses perencanaan: Perumusan tujuan yang ingin dicapai. Pemilihan program untuk mencapai tujuan itu. Identifikasi dan pengerahan sumber yang jumlahnya selalu terbatas.

Sedangkan menurut Musfah (2015) perencanaan yaitu: adanya program kerja atau program kegiatan untuk jangka pendek, menengah, dan jangka panjang serta rencana kerja sekolah. Tujuan dan manfaat program: untuk apa suatu program dilaksanakan, dan dampak atau hasil apa yang akan diperoleh oleh lembaga.

Menurut Sujanto (2007) program-program sekolah yang dilakukan dalam bentuk eksktrakulikuler dan program-program unggulan sekolah sebagai sebuah tambahan identitas bagi sekolah tersebut. Dengan adanya sebuah program identitas sekolah/program unggulan, maka akan membuat minat orang tua untuk mendaftarkan putra/putrinya ke sekolah tersebut dan menjadi daya tarik dalam promosi sekolah. Semakin jelas informasi suatu sekolah yang disampaikan kepada masyarakat maka akan semakin menarik simpati dari masyarakat.

Strategi yang dibuat oleh sekolah dalam penerimaan peserta didik baru, belum fokus kepada strategic goals (visi, misi dan tujuan sekolah). Sekolah belum memanfaatkan keberadaan masyarakat sekitar dalam pemasaran peserta didik baru, tidak menjalin hubungan/kerjasama yang baik dengan PAUD/TK/BIMBA yang ada disekitar lingkungan sekolah, serta belum memanfaatkan alumni dan orang tua alumni, padahal mereka bisa menjadi marketing untuk sekolah.

Menurut Sampurno, manajemen strategik berhubungan dengan analisis mengenai strategic goals (visi, misi dan tujuan) bersama dengan analisis lingkungan internal dan eksternal.

Hubungan sekolah dengan masyarakat menurut Bedjo Sujanto dapat ditingkatkan melalui berbagai jejaring alumni atau dengan menggandeng para tokoh masyarakat yang memiliki pengaruh luas di wilayahnya, dan sekolah membuka peluang bagi para tokoh masyarakat untuk menjadi "pengajar" secara berkala dalam berbagai kegiatan sekolah. Di antara alumni mungkin saja ada yang telah menajdi pejabat pemerintah, pengusaha, dosen, dan berbagai jabatan dan profesi lainnya di tengah masyarakat, yang dapat dimanfaatkan kemampuannya untuk pengembangan pengetahuan dan keterampilan di sekolah.Khususnya untuk pengembangan guru dan siswa, dan sebagai ajang promosi sekolah juga.

Mengadakan lomba di sekolah kemudian mempresentasikan dan memaparkan program-program sekolah. Melihat sisi ekonomi lingkungan sekitar sekolah, maka biaya pendidikan haruslah yang terjangkau/relative murah dibandingkan dengan sekolah IT yang lainnya.

Harus ada solusi yang dapat mengatasi hambatan hambatannya, sehingga tujuan awal dari sekolah dapat terlaksana dengan baik untuk tahun-tahun yang akan datang.

Pelayanan yang diberikan oleh sekolah dari awal proses penerimaan peserta didik baru sampai kelulusan, adanya rasa aman untuk warga sekolah perlu diberikan oleh sekolah dikarenakan sekolah melintasi akses jalan menuju panti rehabilitasi mental. 
Menurut Sukarti, Sururi (2017) komponen peserta didik keberadaannya sangat dibutuhkan, terlebih bahwa pelaksanaan kegiatan pendidikan di sekolah, peserta didik merupakan subyek sekaligus objek dalam proses transformasi ilmu pengetahuan dan keterampilan-keterampilan yang diperlukan. Oleh karena itu keberadaan peserta didik tidak hanya sekedar memenuhi kebutuhan saja, akan tetapi harus merupakan bagian dari kebermutuan dari lembaga pendidikan (sekolah). Artinya bahwa dibutuhkan pengelolaan manajemen peserta didik yang bermutu bagi lembaga pendidikan (sekolah) itu sendiri.Sehingga peserta didik itu dapat tumbuh dan berkembang sesuai dengan potensi fisik, kecerdasan intektual, sosial, emosional, dan kejiwaan peserta didik.

Di dalam bukunya Bedjo Sujanto, mengatakan bahwa: layanan kepada siswa dimulai sejak penerimaan peserta didik baru, penempatan, pembinaan, pengembangan sampai dengan mereka lulus dari sekolah tersebut. Lingkungan sekolah yang aman dan tertib, dengan masyarakat yang memiliki kepedulian yang tinggi terhadap pembinaan sekolah beserta lingkungannya, menjadikan pengelolaan sekolah terus memiliki sikap optimis dan harapan yang tinggi terhadap kondisi sekolah. Hubungan yang harmonis antara sekolah dan masyarakat/orang tua, juga akan mendukung terciptanya iklim sekolah yang sejuk dan baik, sehingga dapat menjadi spirit bagi kemajuan masyarakat yang dilayaninya.

\section{SIMPULAN}

Manajemen sekolah dalam membuat perencanaan diantaranya; adanya program sekolah sebagai ciri khas sekolah/program unggulan, promosi sekolah, mengelola atau mengatur sekolah, bagaimana sekolah dalam mengimplementasikan rencana kerjanya baik jangka panjang, menengah dan pendek sehingga tujuan dapat berjalan maksimal sesuai dengan yang direncanakan di awal, serta adanya usaha kerja sama didalam manajemen sekolah antara kepala sekolah, guru, orang tua, siswa dan masyarakat agar sekolah dapat dikelola secara efektif. Mempunyai manajemen strategik. Manajemen strategik berhubungan dengan analisis mengenai strategic goals (visi, misi dan tujuan) bersama dengan analisis lingkungan internal dan eksternal. Pelayanan sekolah kepada peserta didik dari awal proses penerimaan peserta didik baru sampai kelulusan, bagaimana sekolah memberikan rasa aman, penempatan, pembinaan, pengembangan sampai dengan mereka lulus dari sekolah tersebut, hubungan yang harmonis antara sekolah dan masyarakat/orang tua dapat menjadi spirit bagi kemajuan masyarakat yang dilayaninya.

\section{DAFTAR PUSTAKA}

Fattah, N. (2009). Ekonomi dan Pembiayaan Pendidikan. Bandung: Remaja Rosdakarya

Marini, A. (2014). Manajemen Sekolah Dasar. Bandung: PT. Remaja Rosdakarya Musfah, J. (2015). Manajemen Pendidikan Teori, Kebijakan, dan Praktik. Kencana

Sujanto, B. (2007). Manajemen Pendidikan Berbasis Sekolah: Model Pengelolaan Sekolah Di Era Otonomi Daerah. Sagung Seto

Sukarti, S., \& Sururi, S. (2017). Manajemen Peserta Didik. Bandung: Alfabeta 